\begin{tabular}{l|c|c}
\hline \hline Vol. 28(3):225-236 & Ocean and Polar Research & September 2006 \\
\hline \hline
\end{tabular}

\title{
Article
}

\author{
수중음향을 이용한 해초 서식처(Seagrass Habitats)의 \\ 공간 및 수직 분포 추정 \\ 강돈혁 ${ }^{1 *}$ - 조성호 ${ }^{2}$ 라형술 ${ }^{2}$ - 김종만 ${ }^{1}$ - 나정열 ${ }^{2}$ - 명정구 ${ }^{1}$ \\ 1한국해양연구원 해양자원연구본부 \\ (425-600) 경기도 안산시 안산우체국 사서함 29호 \\ 2한양대학교 과학기술대학 해양환경과학부 \\ (426-791) 경기도 안산시 사 1 동 1271
}

\section{Estimating Spatial and Vertical Distribution of Seagrass Habitats Using Hydroacoustic System}

\author{
Donhyug Kang ${ }^{1 *}$, Sungho $\mathrm{Cho}^{2}$, Hyoungsul $\mathrm{La}^{2}$, Jong-Man Kim ${ }^{1}$, \\ Jungyul $\mathrm{Na}^{2}$, and Jung-Goo Myoung ${ }^{1}$ \\ ${ }^{1}$ Marine Resources Research Department, KORDI \\ Ansan P.O. Box 29, Seoul 425-600, Korea \\ ${ }^{2}$ Major in Earth and Marine Sciences, College of Science \& Technology \\ Hanyang University, Ansan 426-791, Korea
}

\begin{abstract}
Seagrass meadows are considered as critical habitats for a wide variety of marine organisms in coastal and estuarine ecosystems. In many cases, studies on the spatial/temporal distribution of seagrass have depended on direct observations using SCUBA diving. As an alternative method for studying seagrass distribution, an application of hydroacoustic technique has been assessed for mapping seagrass distribution in Dongdae Bay, on the south coast of Korea, in September 2005. Data were collected using high frequency transducer ( $420 \mathrm{kHz}$ split-beam), which was installed with towed body system. The system was linked to DGPS to make geo-referenced data. Additionally, in situ seagrass distribution has been observed using underwater cameras and SCUBA diving at four stations in order to compare with acoustic data. Acoustic survey was conducted along 23 transects with 3-4 knot ship speed. Seagrass beds were vertically limited to depths less than $3.5 \mathrm{~m}$ and seagrass height ranged between 55 and $90 \mathrm{~cm}$ at the study sites. Dense seagrass beds were mainly found at the entrance of the bay and at a flat area around the center of the bay. Although the study area was a relatively small, the vertical and spatial distributions of the seagrass were highly variable with bathymetry and region. Considering dominant species, Zostera marina L., preliminary estimation of seagrass biomass with acoustic and direct sampling data was approximately $56.55 \mathrm{~g} / \mathrm{m}^{2}$, and total biomass of 104 tones (coefficient variation: $25.77 \%$ ) was estimated at the study area. Hydroacoustic method provided valuable information to understand distribution pattern and to estimate seagrass biomass.
\end{abstract}

Key words : seagrass habitat, hydroacoustics, acoustic survey, spatial distribution, seagrass biomass

*Corresponding author. E-mail : dhkang@kordi.re.kr 


\section{1. 서 론}

해초(seagrass)는 현화 식물로 연안 생태계에서 생산력 이 가장 높은 기초 생산자 가운데 하나로, 특히 거머리말 (혹은 잘피, Zostera marina L.)은 세계적으로 널리 분포하 는 우짐종으로 알려져 있다(Short et al. 2001). 해초는 연 안 생태계의 해양 생물학 측면 뿐만 아니라 연안 어류의 서식처 기능으로 인해 수산학 측면에서도 그 중요성이 증 가하고 있다(Connolly 1994; 이 등 2000; Guest et al. 2003; 이 둥 2005). 우리나라의 경우, 대부분의 해초는 서 - 남해안과 제주도 천해역에 주로 분포하고 있으며, 1990년 중반 이후 해초의 생태학적 특성 및 서식하는 생 물에 대한 연구가 진행되고 있다(허와 곽 1997 ; 이 등 2000).

대부분의 해초 서식처는 얕은 천해역이므로 생태 톡성 연구를 위한 현장 조사 및 시료 채취는 대부분 수중 다이 빙을 이용하고 있으며, 어류를 포함한 생물상 연구는 소형 네트를 이용하고 있다. 이러한 조사 방법은 일정 정점에서 채집된 시료를 이용한 생태 특성 연구나 정성 분석에 많 은 장점을 보이고 있다. 그러나 해초는 뿌리를 내릴 수 있 는 해저면 저질 상태(Aioi 1980), 광합성을 위한 수심의 차이(Dennison and Alberte 1985) 등 환경 요인과 계절적 인 수온 차이에 의해 동일한 조사 지역일지라도 다르게 분포하는 특성을 가지고 있다(허 등 1998; 이 2001). 따라 서, 해초의 공간 및 수직 분포 득성과 분포 면적의 변동을 파악하기 위해 다이빙과 같은 직접적인 방법이 가지는 소 규모 조사 정점 수의 한계를 극복할 수 있는 다양한 접근 법이 제시되고 있다(Bergstedt and Anderson 1990; Norris et al. 1997).

해초의 공간 분포, 현존량 및 시간에 따른 변동성을 조 사하고 정량화시키기 위하여 항공기 혹은 인공위성을 이 용한 이미지 처리 기법과 실제 조사선을 이용한 육안 관 찰 둥의 방법이 연구 대상 지역의 면적, 최종 자료의 분해 능과 정확도에 따라 다양하게 선택되고 있다(Mumford et al. 1995), 이 방법들은 광범위 조사가 가능하여 광대역에 서 전체적인 분포 경향을 파악하기에는 적합하나, 기상 상 태 및 해수의 탁도(turbidity)에 따라 영향을 받으며 특히 정확도가 상대적으로 낮아 좁은 지역에서 정밀하게 조사 를 해야 할 때는 한계를 가지고 있다(Dobson et al. 1995).

해초 분포 조사의 정확도를 높이기 위한 헙대역 조사에 서 사용 가능한 방법 가운데 하나는 수중 카메라를 이용 하는 것이다(Norris et al. 1997). 이 방법은 소형 예인체에 수중 카메라를 해저면 방향으로 설치한 후, 조사선을 가능 한 저속으로 운행하면서 녹화된 수중 영상으로부터 해초 의 분포 및 밀도를 간접적으로 예측한다. 이 방법은 해수 의 탁도에 따른 카메라의 해상도와 분포 수심에 따른 카
메라의 탐지 범위에 의해 크게 제약을 받고 있으나, 최종 자료가 시각적인 자료이므로 방형구에 의존하는 기존 연 구 자료보다는 공간 분포 조사에 용이한 장점이 있다.

협대역 혹은 중규모 조사에 적용 가능한 또 다른 방법 은 음퐈를 이용하는 방법이다. 이 방법은 해초 서식처에서 음퐈를 송수신했을 때 해초 체내의 기공에 형성되어 있는 기체로부터 발생하는 음향 산란(acoustic scattering) 특성 을 이용하는 방법으로 1990년 중반에 제안되었다(Sabol et al. 1997, 1998). 수중 음파의 강한 반사체로 작용하는 기체(공기 방울)는 (1) 해초의 줄기(stem) 혹은 잎(blade) 내부의 기공에 존재하고, (2) 해초에서 만들어지는 기포가 해초의 외부 표면에 홉착되거나 수중으로 떨어져 나와 존 재하게 된다. 해초 서식처에 존재하는 이러한 공기방울은 수중 음파에 의해 강한 음향 반사를 일으키므로 최근에 이를 이용한 해초 서식처의 공간 및 수직 분포 연구에 다 양하게 응용되고 있다(Sabol and Johnston 2001; Hoffman et al. 2002; Freitas et al. 2003; Komatsu et al. 2003; 라 등 2005).

우리나라에 분포하는 해초에 대한 연구는 서식처의 생 태계 기능에 주로 주안점을 두고 진행되어 왔기에 대부분 의 조사 방법이 다이빙을 통한 방형구를 이용하였다(Lee et al. 2002; 이 둥 2005). 방형구를 이용한 방법은 제한된 자료 양과 조사 범위로 인해 해초의 공간 및 수직 분포 연 구에 한계가 있으므로 다양한 방법의 적용이 펄요한 시점 이다.

따라서 본 연구에서는 우리나라 연안에 서식하는 해초 의 공간 분포 연구에 사용되는 기존의 방법 이외에 새롭게 적용해야 할 방법 가운데 하나인 수중음향(hydroacoustics) 을 이용한 해초 서식처 조사의 실질적인 적용 가능성을 시도하였다. 이를 위해 남해안에서 광범위한 해초 서식처 로 알려진 득정 지역을 선정하여 음향 조사로부터 해초의 공간 및 수직 분포 특성을 알아보고자 하였으며, 자료 보 강을 위하여 일부 정점에서 수중 카메라 영상과 현장 채 집을 실시하였다. 이러한 접근 방법은 헙대역 혹은 중규모 조사 지역에 대해 해초의 공간 및 수직 분포 특성뿐만 아 니라 계절 변동의 파악이 가능하게 하여 우리나라 연안 해초 서식처의 실제 분포 득성 연구에 적용이 가능할 것 이다.

\section{2. 재료 및 방법}

\section{연구 지역}

음향을 이용한 해초의 수직 및 공간 분포 조사는 경상 남도 남해군의 북쪽에 위치한 창선도의 동대만에서 실시 하였다 $\left(34^{\circ} 53.0^{\prime} \mathrm{N}, 128^{\circ} 1.2^{\prime} \mathrm{E}\right.$, Fig. 1$)$. 이 지역은 기존의 연구 조사로부터 우리나라에서 해초 서식처가 광범위하게 


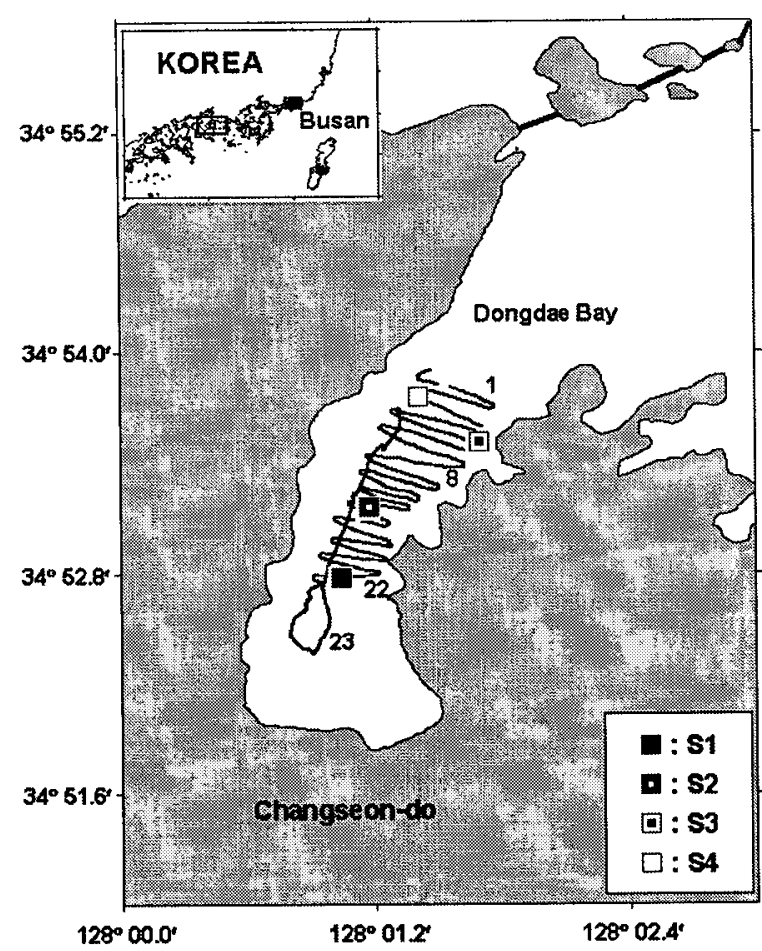

Fig. 1. Survey area and acoustic transect (1-23). Stationary points (S1-S4) indicate positions for seagrass sampling and underwater camera.
발달한 지역 가운데 하나로 알려져 있는 곳이다(이 등 2005). 동대만은 남북 방향으로 길고 동서 방향으로 좁은 내만의 지리적 형태를 가지고 있으며, 간조 때 만의 바깥 쪽으로 개펄이 드러나는데 조석차는 평간 해수면을 기준 으로 $-0.2 \sim 3.7 \mathrm{~m}$ 의 변위를 가지고 있다. 만 중앙부와 동 쪽 부분에 골이 형성되어 있으며, 음향 측심기로 측정된 최대 수심은 만의 중앙 동쪽 부분에서 약 $9.2 \mathrm{~m}$ 정도이 다. 동대만의 전체 면적은 만 입구의 적용 범위에 따라 차 이가 있지만 약 $4.12 \times 10^{6} \mathrm{~m}^{2}$ 이다.

\section{음향 시스템 및 현장 조사}

음향 조사는 2005년 9월 27일에 실시하였으며, 현장 조 사에 사용된 음향 장비는 입력 변수 제어 및 음향 자료 송 - 수신을 유-무선으로 할 수 있는 통합 시스템이다 (BioSonics 2005). 해초 탐지를 위한 음향 센서는 분할 빔 (split-beam) 방식을 사용하는 $420 \mathrm{kHz}$ 센서로 빔 폭은 $6^{\circ}$, 수신 신호의 역치는 $-130 \mathrm{~dB}$ 로 미세 신호까지 수신이 가 능하다. 해초의 음향 신호를 수신하기 위하여 송신 신호의 폭(pulse width)은 $0.1 \mathrm{~ms}$, 센서의 송신 간격(ping interval) 은 0.2 초이다. 한편, 관촉에 사용된 센서의 수직 분해능은 약 $1.76 \mathrm{~cm}$ 로 고분해능의 수직 해상도를 가지고 있다.

현장 조사는 조사 지역의 수심이 얕아 연안으로 접근하 기 어렵기 때문에 음향 센서를 직접 예인하는 방법 대신
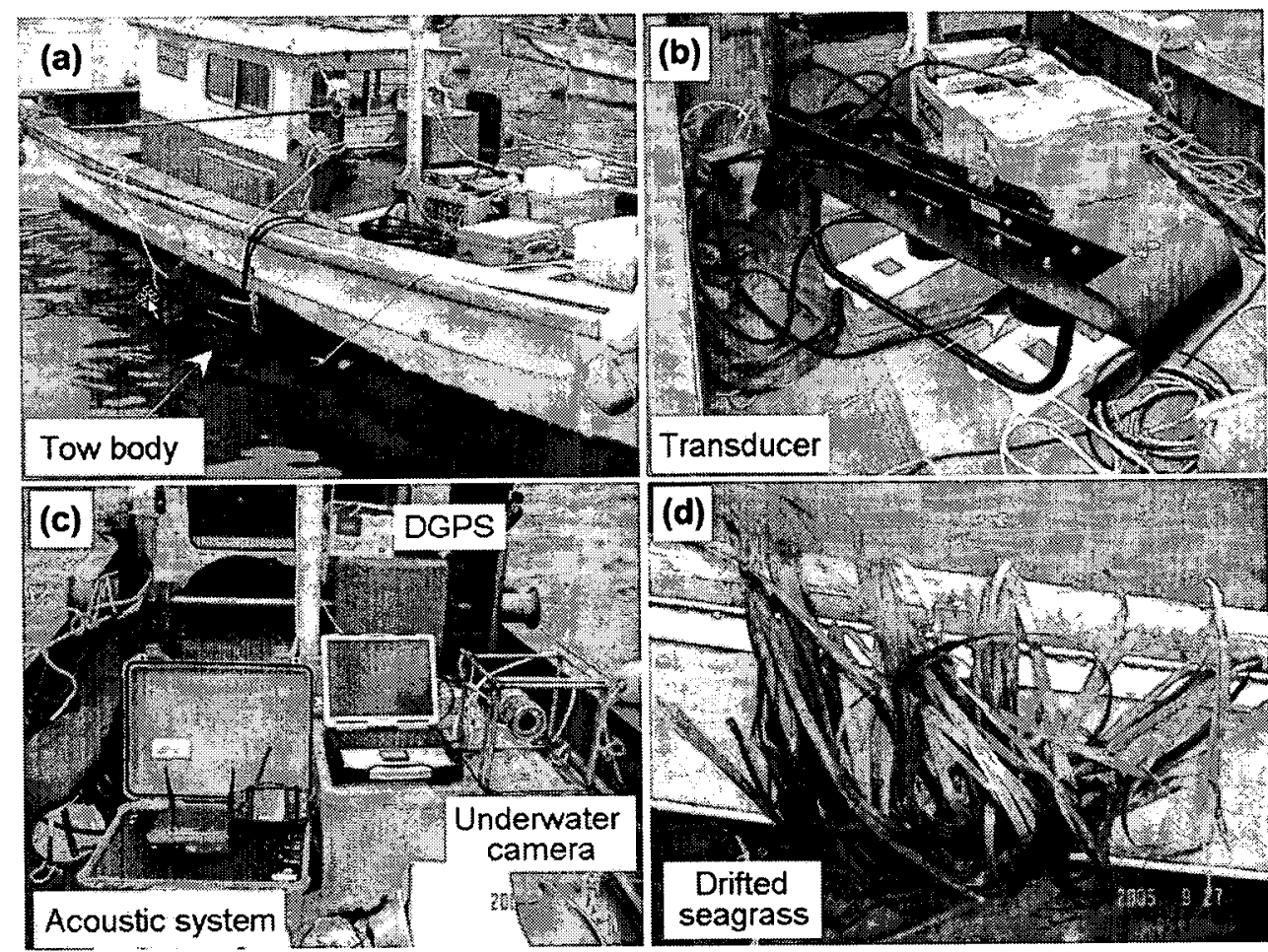

Fig. 2. Experimental facilities and seagrass; survey ship \& towed-body (a), acoustic transducers (b), sound unit system $\&$ underwater camera (c), and drifted seagrass (d). 
소형 선박의 오른쪽 중앙부에 예인체를 고정한 후에 예인 하는 방식을 이용하였다(Fig. 2(a)). 예인체의 수심은 해수 면으로부터 약 $0.5 \mathrm{~m}$ 로 일정하게 유지하였다. 소형 예인 체에 부착한 센서는 해초 탐지를 위한 $420 \mathrm{kHz}$ 센서 이외 에 $200 \mathrm{kHz}$ 음향 센서를 부착하였다(Fig. 2(b)). $200 \mathrm{kHz}$ 음향 센서의 내부에는 기울기 센서 및 방위각 센서가 독 립적으로 내장되어 있어 예인체의 안정성을 실시간으로 파악하여 예인 속도를 결정하였다. 예인 속도는 예인체의 안정성 정도와 예인체 주변에 형성되는 기포의 영향을 고 려하여 3 4 노트로 유지하였다.

조사 지역이 외해에 비해 상대적으로 좁은 만이므로 음 향 자료의 정확한 위치 정보를 위하여 GPS 보다 해상도 가 높은 DGPS(Differential Global Positioning System)를 이용하여 매 1 초 간격으로 음향 자료와 함께 위치 정보를 저장하였다. 음향 조사는 동대만의 바깥 부분에서 안쪽으 로 이동하며 실시하였으며, 육지와 인접한 연안쪽의 수심 이 얕아 접근이 어려운 점을 고려하여 조사선의 이동은 삼각형 격자 경로(triangular grid track) 방법을 이용하였 다. 총 음향 정선 수는 23개로 22개 정선은 동대만을 가로 지르는 동서 방향 경로이며, 나머지 1개는 동일한 수심을 이동하는 남북 방향 경로이다(Fig. 1). 내만의 특성상 육지 와 인접한 곳의 수심이 $1 \mathrm{~m}$ 내외로 얕아 만 내부의 모든 지역을 조사하기에는 불가능하였으나, 조사선이 이동 가 능한 최소 수심까지 접근을 시도하였다. 각 음향 정선의 끝 부분(way point)을 연결하여 계산한 음향 조사 면적은 약 $1.84 \mathrm{~km}^{2}$ 로 동대만 전체 면적의 $44.7 \%$ 에 해당하였다.

조사 시기는 동대만 일대의 9월 조석 주기 가운데 조차 가 가장 작은 소조(neap tide)의 시기이며, 연구 지역에서 조위의 기준면은 평균 해면하 $165 \mathrm{~cm}$ 이다. 음향 조사는
14:00 17:40 사이에 실시되었으며, 이 시간대의 조석은 간 조 $(10: 38,142 \mathrm{~cm})$ 에서 만조 $(18: 09,234 \mathrm{~cm})$ 로 변하는 시 간대였다.

\section{음향 자료 처리}

본 연구에서 사용된 음향 시스템에서 해초의 분포 유무 를 판단하기 위하여 $1.76 \mathrm{~cm}$ 의 고분해능 수직 해상도 자 료 가운데 해초와 해저면이 서로 닿아있는 부분의 수신 신호 기울기(receiving signal's slope)를 이용하였다. 각각 의 수직 분해능 내에서 수신된 신호를 데시벨(decibel, $\mathrm{dB}$ ) 단위로 나타낸 후, 해저면에 의한 수신 강도와 해초 줄기 부분이 시삭되는 해저면 근처의 수신강도를 비교하 게 된다.

조사 지역의 한 정선에서 해초가 없는 지역과 있는 지 역에서 각각 수신된 음향 신호는 개개 에코그램의 해저면 부근에서 서로 차이를 보여주고 있다(Fig. 3(a, b)). 해초가 없는 곳에서 수신된 음향 신호는 해저면에 도달하는 지점 에서 해수를 통과하는 수신 신호와 약 $50 \sim 60 \mathrm{~dB}$ 차이의 큰 음압 기울기를 가진다(Fig. 3(a), ping number: P1). 이 러한 이유는 해수 중 음향 산란체가 없기 때문에 낮은 수 신강도를 나타내다가 해저면에 도달하는 순간 강한 음향 산란 특성을 보이기 때문이다. 그러나 해초가 분포하는 지 역에서는 해저면에 의한 수신 신호와 해저면 부근의 해초 에 의한 음향 신호 차이는 상대적으로 작은 약 $1020 \mathrm{~dB}$ 의 음압 기울기를 가진다(Fig. 3(b), ping number: P2).

음향 신호로부터 해초의 존재 유무가 판별되면 다음 과 정으로 해초의 길이(height, $\mathrm{cm}$ )와 분포 비율(coverage, $\%$ )를 계산하는 과정을 거치게 된다(Fig. 3(c)). 해초의 길 이는 수신 신호의 수직 분포로 계산하게 되는데, 이때 해

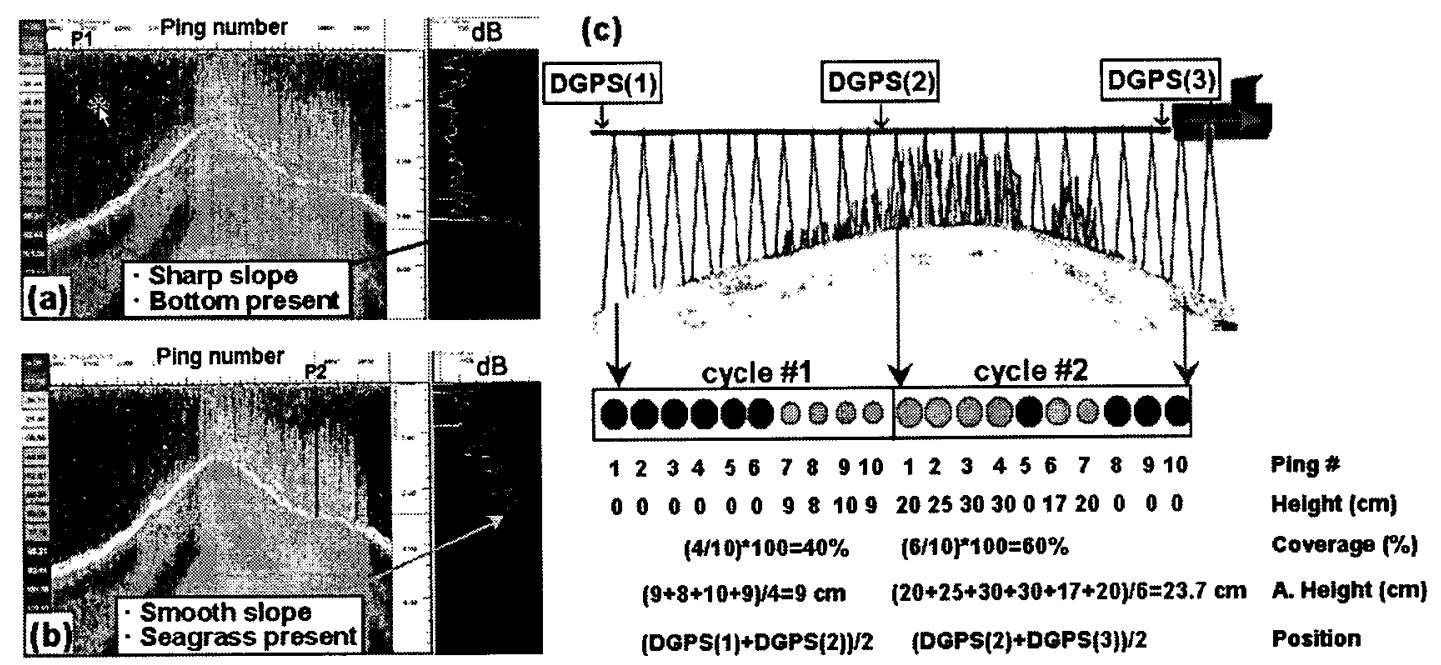

Fig. 3. Analytical algorithm to determine seagrass bed (ping P1, (a)) \& non-seagrass bed (ping P2, (b)), and to calculate seagrass height, coverage and position. 
초에 의한 수신 음압 크기는 해초의 크기에 따라 다르지 만 연구 지역에서 수신된 음향 자료에서는 $-15 \sim-60 \mathrm{~dB}$ 의 범위 내에 있게 된다. 수신 신호의 수직 분포에서 이 범위에 드는 수신 깊이를 해초의 길이로 처리하게 된다.

해초의 분포 범위는 하나의 수신 신호로 계산하지 않고 여러 개의 수신 신호를 하나의 자료로 묶어(cycle) 계산하 게 되는데 본 연구에서는 15 개의 수신 신호를 1 cycle로 이용하였다. 15 개의 수신 신호는 조사선의 이동 속도와 0.2 초의 송신 간격을 고려하면 약 $6.2 \mathrm{~m}$ 의 수평 거리에 해 당한다. Fig. 3(c)의 예는 10개의 수신 신호를 $1 \mathrm{cycle}$ 로 정의했을 때 계산되는 해초의 길이, 분포 범위, 평균 길 이, 각 cycle의 평균 위치에 대한 계산 과정을 보여주고 있다.

\section{Seagrass의 수중 촬영 및 채집}

본 연구에서 해초의 분포 특성을 파악하기 위하여 사용 된 방법은 간접적인 방법인 음향 조사 방법이다. 따라서, 간접적인 방법으로부터 얻어지는 자료를 통한 해초의 존 재 유- 무를 검증하기 위하여 직접적인 방법에 해당하는 수중 카메라 이용과 현장 채집을 실시하고자 하였다.

이를 위하여 총 23 개 정선에 걸쳐 음향 자료를 실시간 으로 저장하면서 수신된 음향 자료로부터 수신 강도에 따 라 해초의 분포 지역을 4지점으로 구분하여 만 안쪽의 중
앙부(S1), 중간 지역의 서쪽(S2) 및 입구의 동쪽과 서쪽 (S3, S4)에서 각각 좌표를 결정하였다(Fig. 1). 이때, 음향 수신 강도가 강한 지역을 2 지점, 음향 수신 강도가 중간 정도인 곳과 마지막으로 미약한 지역을 각각 1 지점씩 선 정하여 음향 자료와 비교하기 위하여 수중 영상 촬영 및 채집을 실시하였다. 줌 기능, 자동 초점 기능과 LED 램프 가 내장되어 있는 수중 카메라를 사각형 스테인레스 틀에 고정시켜 해초 분포 수심까지 내린 후 디지털 영상 자료 를 저장하였다(Fig. 2(c)).

한편, 해초 채집은 수중 카메라 촬영 지점과 동일한 좌 표에서 가로, 세로가 각각 $35 \mathrm{~cm}$ 인 방형구를 이용하여 각 정점 당 2 회씩 다이버가 직접 실시하였다. 이때 방형구 내 에 서식하는 해초는 모두 거머리말(혹은 잘피, Zostera marina L.)로 서식 개체수를 계수하였으며(shoot density), 뿌리 부분을 절단한 상부에서 부착 해조류를 제거한 후에 건조 중량(above shoot biomass, $\mathrm{g} \mathrm{DW}$ )을 측정하였다.

\section{3. 결 과}

해초 음향 조사는 삼각형 격자 경로(triangular grid track) 방식을 이용하여 연구 지역인 동대만 입구에서 안 쪽을 향하는 22 개의 정선과, 추가로 만 내부에서 바깥쪽 방향으로 $2 \mathrm{~m}$ 의 등수심을 이동하는 정선에서 실시되었
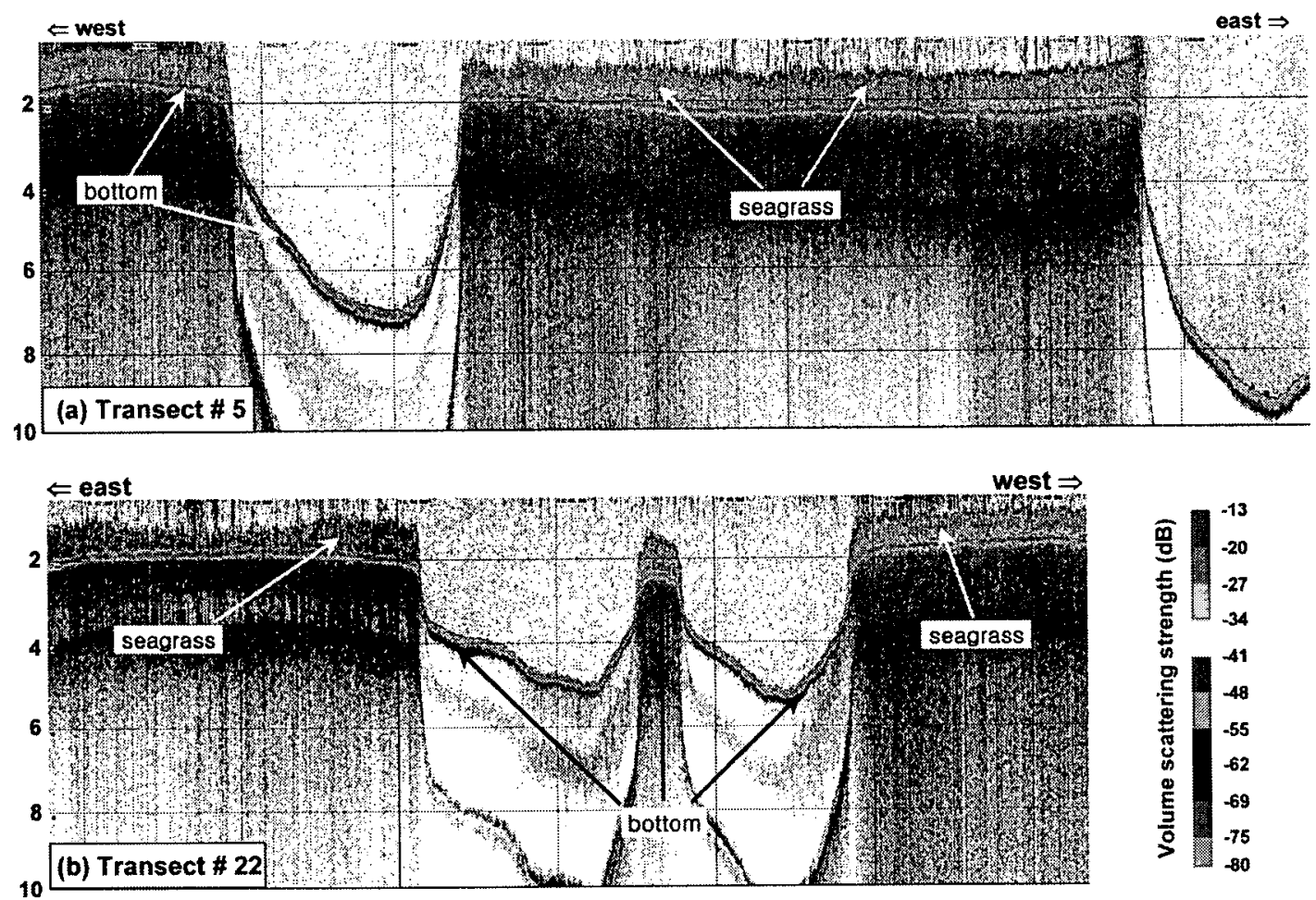

Fig. 4. Vertical distribution of the seagrass along transects 5 and 22. Red color indicates dense seagrass. Almost seagrass distributes depths above $3 \mathrm{~m}$. 
다. 음향 조사의 정선간 거리는 각 정선의 중간 위치를 기 준으로 할 때 최소 $63 \mathrm{~m}$, 최대 $153 \mathrm{~m}$ 이었다. 한편, 22 개 정선 가운데 최소 정선 거리는 $350 \mathrm{~m}$, 최대 정선 거리는 약 $810 \mathrm{~m}$, 등수심을 따라 이동한 정선의 거리는 약 $2560 \mathrm{~m}$ 였으며, 전체 음향 조사의 총 거리는 $11.94 \mathrm{~km}$ 였다.

\section{Seagrass의 수직 분포}

조사 시간동안 조위는 평균 해수면(mean sea level)보다 최대 $69 \mathrm{~cm}$ 높았으며, 14:00 17:40 시간대의 평균 조위는 평균 해수면보다 약 $40 \mathrm{~cm}$ 정도 높았다. 따라서 음향 조 사에서 기술하는 모든 수심은 $40 \mathrm{~cm}$ 정도의 편차를 가지 고 있다.

음향 조사에서 관측된 동대만의 지형은 만의 위치에 따 라 다르게 나타나고 있었다. 동대만 입구인 정선 1에서 만 의 중앙부에 해당하는 정선 11 까지는 서쪽과 중앙부에서 약 $1.62 .3 \mathrm{~m}$ 의 평탄한 지형 분포를 보이고 있었으나, 서 쪽과 중앙부 사이와 만의 동쪽 부분에서는 약 7 9 $\mathrm{m}$ 의 급격한 수심 변화를 가지는 골이 형성되어 있었다. 만의 안쪽 부분에 해당하는 정선 12 22의 중앙부는 수심 $5 \mathrm{~m}$ 정도인 두 개의 골이 형성되는 지형 특성을 가지고 있다. 이들 지형 분포는 동대만에 서식하는 해초의 수직 분포와 직접적인 연관성을 가지는 것으로 나타나고 있다.

동대만의 입구 부분에 해당하는 정선 5 에서의 음향 신 호는 해초의 수직 분포 특성을 보여주고 있다(Fig. 4(a)). 연구 지역에서 거머리말은 대부분 수면 근처 아래의 $1.5 \sim 2.2 \mathrm{~m}$ 수심에 분포하고 있었으며, 최대 분포 수심은 약 $3.5 \mathrm{~m}$ 로 그 이하에는 없는 것으로 나타나고 있다. 한 편, 동대만에 분포하는 해초는 약 $55 \sim 90 \mathrm{~cm}$ 의 길이를 보 이고 있었다. Fig. 4(b)는 가장 안쪽의 해당하는 정선 22번 에서 거머리말의 수직 분포를 보여주고 있다. 최대 분포 수심은 가운데 골의 능선 부분에서 약 $2.7 \mathrm{~m}$ 수심까지이 며, 정선의 동쪽과 서쪽 부분에서는 약 $1.8 \mathrm{~m}$ 수심까지 해 초가 존재하는 것으로 나타났다. 전체적인 음향 신호를 고
려할 때, 조사 지역에서 해초의 분포는 최대 $3 \mathrm{~m}$ 보다 얕 은 수심에 걸쳐 분포하는 특성을 보여주고 있으며, 대부분 은 수심 $2 \mathrm{~m}$ 근처에 서식하는 것으로 나타나고 있다. 따 라서 음향 조사로부터 동대만에서 해초는 전 지역에 균일 하게 분포하는 것이 아니라 대부분 약 $2.7 \mathrm{~m}$ 의 수심을 기 준으로 그 보다 깊은 수심에는 해초 분포가 미약하거나 거의 없음을 보여주고 있다.

\section{Seagrass의 분포 밀도 및 길이}

Fig. 4에서 보여주는 음향 자료는 해초의 수직 분포 및 길이 특성 이외에 수신된 신호의 음향 수치(acoustic backscattering strength, $\mathrm{dB}$ )를 데시벨 단위로 표시하여 해 초의 분포 강도를 나타내고 있다. 적색 계열로 표시되는 $-20 \mathrm{~dB}$ 부근의 음향 강도는 해초의 분포 밀도가 높은 지 역을, 녹색 계열로 표시되는 $-45 \mathrm{~dB}$ 부근은 분포 밀도가 상대적으로 낮은 지역을 의미하고 있다.

정선 5 번의 음향 정선에서 해초의 분포 밀도는 정선 중 앙부에서 일부 약하게 나타날 뿐 전체적으로 높은 분포 밀도를 나타내고 있다. 반면 조사 정선 가운데 가장 안쪽 에 해당하는 정선 22에서는 정선의 서쪽 부분의 해초 분 포 밀도가 동쪽에 비해 상대적으로 높게 나타남을 보여주 고 있다. 이러한 음향 자료는 해초의 수직 분포 특성과는 독립적으로 동일한 수심일지라도 공간 분포 특성이 다를 수 있음을 보여주고 있으며, 또한 좁은 만과 같은 지역에 서도 해초의 공간 분포 파악을 위해서는 조사 간격을 가 능한 좁게 설정해야 함을 나타내고 있다.

Table 1은 Fig. 3에서 기술한 음향 자료 처리 과정의 결 과를 일부분 보여주고 있다. 15 개의 음향 신호로 구성된 하나의 cycle에서 해초의 평균 길이(mean height, $\mathrm{m}$ )와 피 도(coverage, \%)를 나타내고 있다. 10 개의 cycle에서 평균 길이는 $0.22 \sim 0.84 \mathrm{~m}$, 피도는 $20 \sim 100 \%$ 를 가지고 있음을 보여주고 있다. 이때 해초의 존재 지표 $(N, p i n g)$ 는 개개 ping에 대해 해초가 존재하면 " 1 "로, 없을 때는 " 0 "으로

Table 1. An example of numerical analysis with acoustic data. The results were obtained from Fig. 3(c).

\begin{tabular}{ccccccc}
\hline Cycle & Latitude & Longitude & Mid Ping \# & $\begin{array}{c}\text { Mean height } \\
(\mathrm{m})\end{array}$ & $\begin{array}{c}\text { Coverage } \\
(\%)\end{array}$ & $\begin{array}{c}\text { Index of seagrass } \\
(\mathrm{N})\end{array}$ \\
\hline 1 & 34.89690 & 128.02594 & 6 & 0.78 & 100.0 & 15 \\
2 & 34.89687 & 128.02603 & 19 & 0.80 & 93.3 & 14 \\
3 & 34.89685 & 128.02609 & 34 & 0.72 & 93.3 & 14 \\
4 & 34.89684 & 128.02612 & 49 & 0.80 & 86.7 & 13 \\
5 & 34.89682 & 128.02618 & 64 & 0.84 & 100.0 & 15 \\
6 & 34.89681 & 128.02623 & 79 & 0.75 & 93.3 & 14 \\
7 & 34.89680 & 128.02628 & 94 & 0.70 & 93.3 & 14 \\
8 & 34.89678 & 128.02634 & 109 & 0.57 & 73.3 & 11 \\
9 & 34.89677 & 128.02637 & 124 & 0.48 & 46.7 & 7 \\
10 & 34.89676 & 128.02640 & 139 & 0.22 & 20.0 & 3 \\
\hline
\end{tabular}



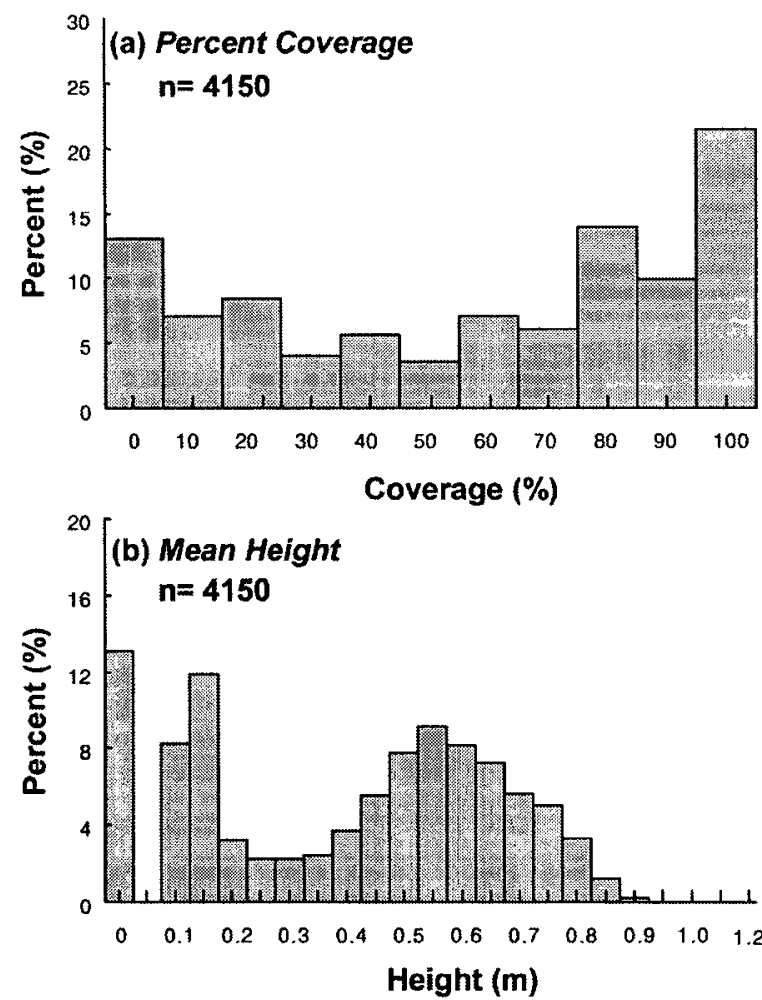

Fig. 5. Percent coverage (a) and mean height of the seagrass using acoustic data at the study area. Considering ecological characteristics of the seagrass, it is possible that the height below 0.2 $m$ might be not seagrass in the mean height.

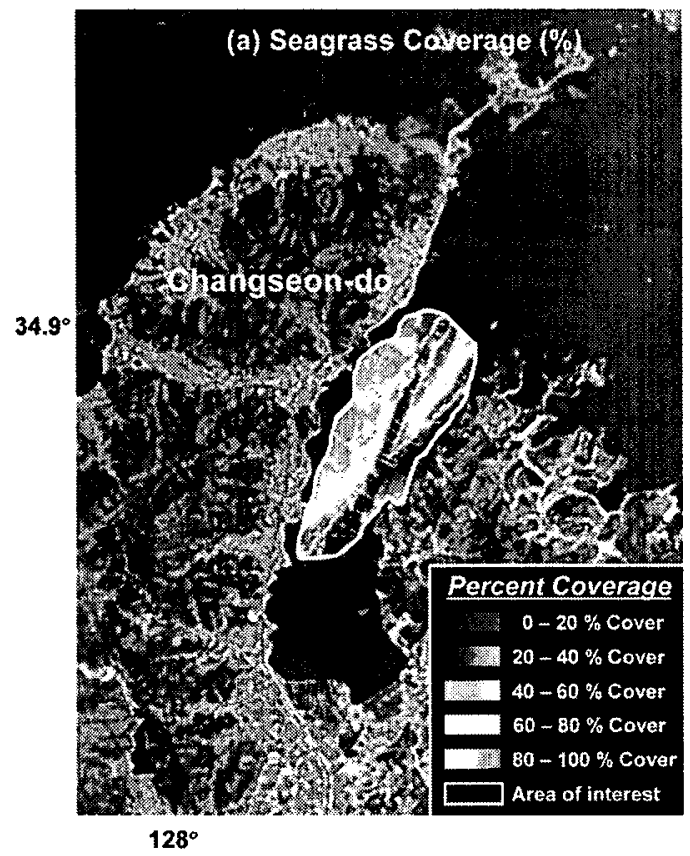

표시되는데, 만일 하나의 cycle인 15 개 ping 가운데 10 개 의 ping에서 해초가 탐지되면 $N$ 은 “ 10 ”으로 표시되며 이 때 피도는 $10 / 15=66.7 \%$ 를 가지게 된다.

전체 음향 정선은 4,150 개의 cycle로 구성되었으며 이 들 전체 자료로부터 해초의 분포와 평균 길이의 구성 비 율을 알아보았다(Fig. 5). 수신된 음향 신호의 개개 cycle 을 기준으로 할 때, 해초가 $50 \%$ 이상을 차지하는 비율은 전체 4,150 개의 cycle 가운데 약 $61.8 \%$ 를 차지하고 있었 으며, 해초가 $30 \%$ 이하인 경우는 전체 cycle 가운데 약 $32.5 \%$ 를 차지하고 있었다. 특히, 해초가 $80 \%$ 이상을 차지 하는 비율은 음향 신호에서 약 $45.3 \%$ 를 차지하여 동대만 저서 환경에서 해초가 차지하는 면적이 높게 나타남을 보 여주고 있다. 해초의 길이는 $50 \mathrm{~cm}$ 이상의 길이를 가진 비율이 전체 음향 신호 가운데 약 $48 \%$ 를 차지하고 있었 다. 한편, $20 \mathrm{~cm}$ 미만의 작은 길이를 가진 음향 산란체의 비율이 약 $36 \%$ 를 차지하는 것으로 나타나고 있다. 조사 시기가 9월 하순인 것을 고려하면 해초의 성장 특성을 고 려할 때 해초보다는 해조류나 그밖에 다른 음향 산란체일 가능성을 내포하고 있다. 이러한 가능성을 본 연구에서는 고려하지 않아 향후 연구에서는 이에 대한 추가 연구의 필요성이 있다.

음향을 이용한 해초의 길이 및 분포 연구 결과는 해초 생테학에서 사용하는 방법에서 나오는 결과와 비교할 때 오차를 가질 수 있다. 즉, 음향을 이용한 방법은 현장에서 직접 측정하는 방법이므로 조사 당시의 해류나 조류에 의 해 해초가 흔들리거나 기울어진 상태를 촉정할 가능성이

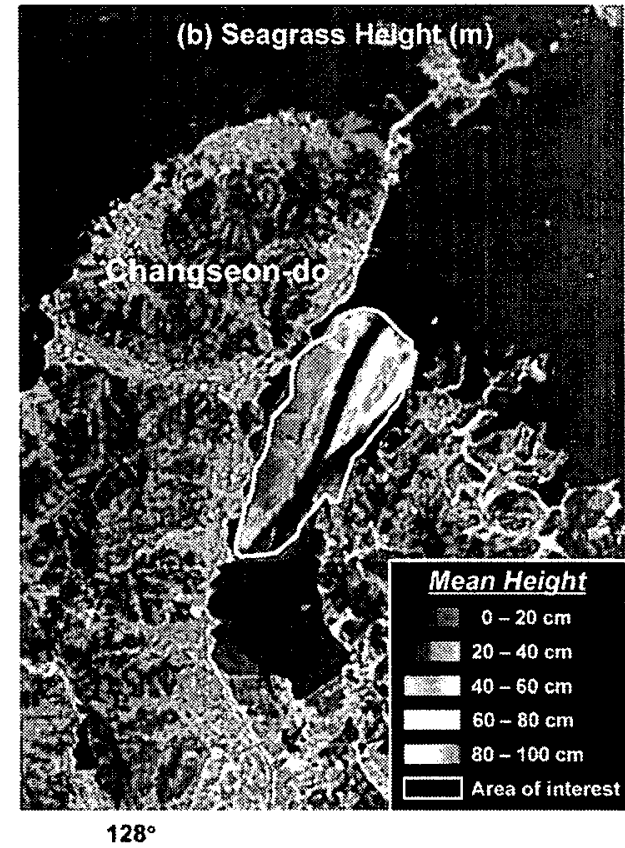

Fig. 6. Spatial distribution on the coverage $(\%)$ and mean height $(\mathrm{m})$ of the seagrass at Dongdae Bay. 
있어 전쳬적으로 해초의 최대 길이가 낮게 측정될 수 있 다. 이러한 음향 조사 기법은 현장 조사의 일부 단점에도 불구하고 짧은 시간에 걸쳐 넓은 공간에 대해 해초의 수 직 분포 및 평균 길이를 파악할 수 있는 장점이 있어 해초 연구에 또 다른 방법론을 제시하고 있다.

\section{Seagrass의 공간 분포 특성}

수신된 모든 음향 신호의 cycle로부터 계산된 해초의 지리적 분포 특성과 평균 길이를 동대만의 공간 지도에 포시하였다(Fig. 6). 동대만에서 해초의 지리적 분포는 크 게 두 가지 톡성으로 분리되었다. 만의 중앙부와 동쪽에 위치한 수심 $5 \mathrm{~m}$ 이상의 V-자 형태의 골짜기에는 해초의 분포가 빈약하거나 거의 없는 것으로 나타난 반면 대부분 의 해초는 수심 $3 \mathrm{~m}$ 이내의 얕은 수심에 제한되어 분포하 는 형태를 보이고 있었다. 해초 분포 범위(coverage)가 $60 \%$ 이상으로 가장 크게 나타나는 지역은 동대만의 입구 부분과 두 개의 골짜기 사이에 위치한 평탄한 지역이었 다. 한편, 동일한 수심일지라도 분포 경향이 다양하게 나 타나고 있었으며 동대만 안쪽의 경우에는 만의 서쪽 부분 에서 넓은 분포 범위를 보여주고 있었다.

해초의 길이는 서식 밀도가 높은 지역에서 상대적으로 길이가 큰 것으로 나타나는 상관성을 보여주고 있다. 즉, 만의 입구 부분과 두 개의 골짜기 사이에 위치한 평탄한 지역에 존재하는 해초의 길이가 가장 크게 나타났으며, 이 들 지역에서 해초는 평균 길이가 약 $60-80 \mathrm{~cm}$ 의 길이 분 포를 가지고 있었다. 그 외의 해초 분포 지역은 $40-60 \mathrm{~cm}$ 의 해초가 주로 존재하는 것으로 나타나, 좁은 만 내부일
지라도 서식 밀도 및 해초 길이의 변동성이 크게 나타남 을 보여주고 있다.

\section{음향 자료와 수중 카메라 영상의 비교}

네 지점에서 관측한 수중 카메라 영상은 각 지역에 따 라 서로 다른 해초의 분포 모습을 보여주고 있었다(Fig. 7). 만 안쪽의 중앙 지역에서는(S1) 해초의 존재가 없이 저질로만 구성되어 있었으며, 만 중간의 서쪽 지역은 해초 의 분포 밀도가 크지 않은 것으로 나타났다. 이들 두 지역 과는 다르게 만 입구 부분의 서쪽(S3)과 동쪽(S2) 지역은 수중 카메라 영상 자료에서 해초의 분포 밀도가 높은 것 으로 나타났다.

Fig. 6에 보여주고 있는 수중 음향 방법을 이용한 동대 만 전체에 대한 해초의 공간 분포도에서 수중 카메라 조 사 지점의 해초 분포 특성을 보면 네 지점 모두에서 수중 음향 방법과 수중 카메라에 의한 해초 분포 특성의 상관 성이 양호함을 보여주고 있다. 즉, S1 지점은 수중 카메라 영상에서 해초의 존재가 없는 상태로 Fig. 6의 음향 자료 에서도 해초는 $0-20 \%$ 의 분포 범위를 나타내고 있으며, S4 지점처럼 수중 영상에 해초 밀도가 큰 지역에서 음향 자료에서 해초는 $80-100 \%$ 의 분포 범위를 가지고 있음을 보여주고 있다.

\section{4. 고 찰}

해초는 어류의 서식처, 산란장 및 피난처를 제공해 주 어 천해의 수산 자원 측면에서 다양한 서식 환경을 제공

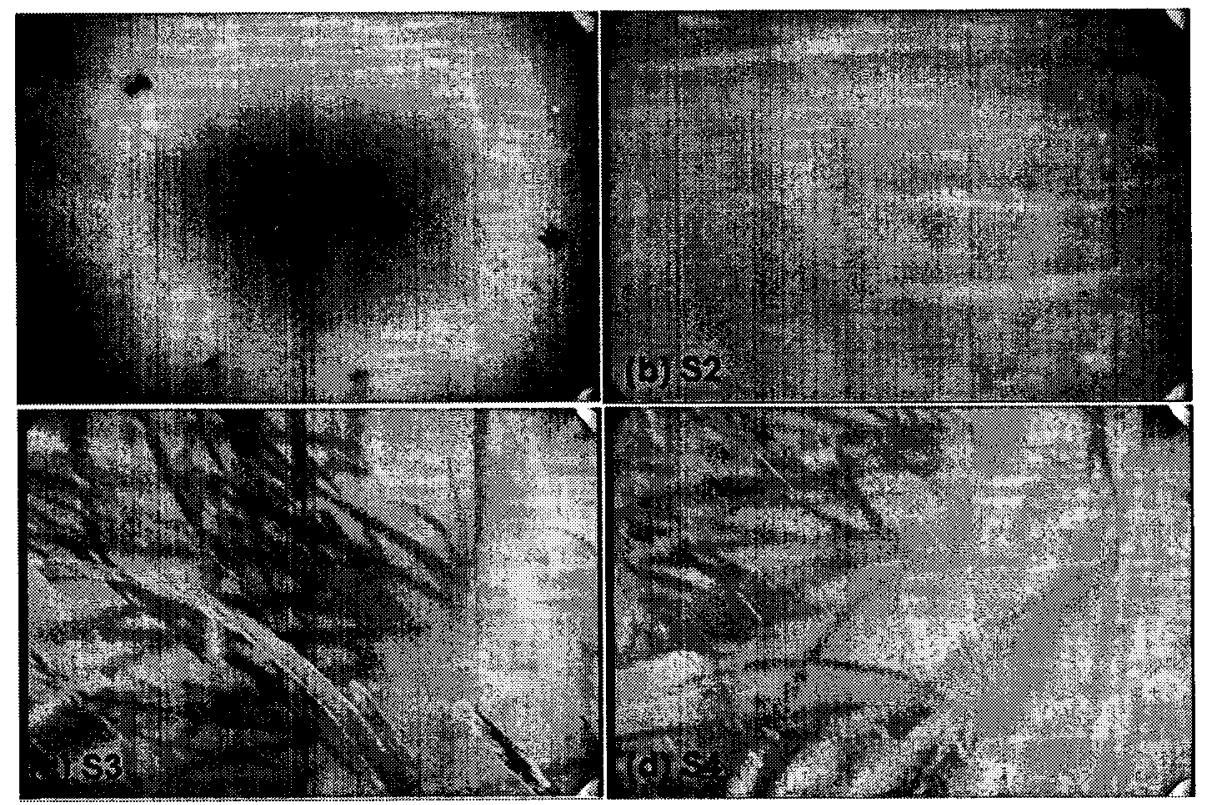

Fig. 7. Photographic image using underwater camera. 
해 주며, 생태학 측면으로도 중요성이 큰 자원으로 다양한 연구 방법이 사용되어져 왔다. 우리나라에서 수행되고 있 는 다양한 연구 방향 가운데 해초 서식처에 대한 공간 분 포 연구는 대부분 다이빙을 통한 직접 방법으로 얻어진 일부 자료를 이용하고 있다. 본 연구는 우리나라 천해에 서식하는 해초의 수직 및 공간 분포를 자세히 알아보기 위하여 기존의 다이빙을 통한 직접 채집 방법이 가지고 있는 소규모 조사 정점 수의 한계를 극복하기 위한 대안 으로 수중음항을 이용한 방법을 적용하고자 하였다.

연구 지역인 남해도 동대만의 면적은 약 $4.12 \times 10^{6} \mathrm{~m}^{2}$ 이고, 음향 조사 면적은 $1.84 \times 10^{6} \mathrm{~m}^{2}$ 으로 전체 만 면적의 $44.6 \%$ 에 해당하였다. 그러나 조사 선박이 접근하기 어려 운 수심 $1 \mathrm{~m}$ 이내의 얕은 곳을 제외한다면 실제 음향 조 사 면적은 전체 면적의 약 $60 \sim 70 \%$ 이상을 차지하고 있 다. 조사 지역에서 음향 조사 시간은 조사선의 이동 속도 를 약 3 4 노트로 하였을 때 총 4시간 20분 만이 소요되 었으며, 일부 수 층이 아닌 전 층에 대한 해초의 음향 반 사 특성 자료를 취득하였다. 이러한 짧은 조사 시간은 조 사 정선 간격을 더 세밀히 진행한다고 해도 공간 분포 특 성의 파악을 위한 기존의 다이빙 방법이 가지는 시간적 제약 요소를 극복할 수 있으며, 특히 조사 시간의 여유 시 간 확보가 가능하여 반복 조사가 가능한 장점이 있다. 한 편, 다이빙을 통한 해초의 수직 분포 특성 파악을 위해서 는 다이빙을 위한 시야 확보가 필요하나 해초 서식처 대 부분에서 다이빙을 위한 시야가 불량하여 많은 어려움을 주고 있다. 음향 조사 방법은 이러한 문제점의 극복이 가 능하여 전 수층에 대한 해초의 수직 분포 특성 파악이 가 능하게 된다.

수중음향을 이용한 방법은 간접적인 여러 가지 방법 가 운데 하나로 해초의 수직 및 공간 분포 연구에는 유용한 방법이나 종 식별은 현재로서는 불가능하다. 한반도 연안 에 서식하는 해초는 거머리말, 왕거머리말(Z asiatica Miki), 수거머리말(Z. caulescens Miki), 포기거머리말( $Z$. caespitosa Miki), 애기거머리말(Z. japonica Ascherson and Graebner) 등 여러 종류가 분포하고 있는 것으로 알려 지고 있다(이 둥 2005). 이들 종이 동일 해역에 비슷한 분 포 비율로 혼재되어 나타나는 경우에는 큰 의미의 해초류 로 정의하여 적용이 가능할 뿐 종별로 분포 특성이나 밀 도 추정은 어렵게 된다. 그러나 특정 해역에서 채집을 통 해 어느 한 종이 우점하여 나타나는 경우에는 우점종에 대한 정보를 알 수 있으므로 수중음향 기법을 이용하여 분포 특성이나 밀도 추정을 시도할 수 있다.

음향 조사로부터 해초의 공간 분포는 동일한 지역일지 라도 위치에 따라 편차가 심하게 나타나므로 작은 횟수의 직접적인 채집 자료로부터 해초의 현존량을 추정하는 방 법은 어려움을 가질 수 있음을 알 수 있다. 본 연구에서
Table 2. Shoot density and total biomass of the sampled seagrass, Zostera marina L.

\begin{tabular}{cccccc}
\hline \multirow{2}{*}{ Station } & \multicolumn{2}{c}{$\begin{array}{c}\text { Shoot density/ } \\
\text { Quadrate }\end{array}$} & & \multicolumn{2}{c}{$\begin{array}{c}\text { Total biomass DW } \\
\left(\mathrm{g} / \mathrm{m}^{2}\right)\end{array}$} \\
\cline { 2 - 3 } \cline { 5 - 6 } & Sampling 1 & Sampling 2 & & Sampling 1 & Sampling 2 \\
\hline 1 & 7 & 12 & & 30.5 & 24.4 \\
2 & 12 & 8 & & 49.7 & 48.2 \\
3 & 34 & 24 & & 330.9 & 220.3 \\
4 & 10 & 15 & & 68.3 & 85.4 \\
\hline
\end{tabular}

mean dry weight $(\mathrm{DW})=0.861 \mathrm{~g} \mathrm{DW} /$ individual

사용된 음향 자료는 연속적인 자료로 직접적인 채집 방법 에 비해 자료의 양이 많으므로 음향 자료와 채집 자료를 이용하여 해초의 현존량을 추정하였다.

동대만의 경우 해초류 가운데 거머리말이 우점하는 것 으로 알려져 있으며(이 2001), 본 연구 기간 중 방형구로 채집된 해초류 또한 거머리말로 이루어져 있었다. 따라서 음향 자료를 통한 해초류의 현존량 추정은 거머리말의 현 존량으로 가정하였다. 총 4 정점에서 정점 당 2 회에 걸쳐 채집된 122 개체의 거머리말에서 뿌리 부분을 제외한 개체 당 평균 건조 중량은 약 $0.861 \mathrm{~g}$ 이다(Table 2). 방형구의 면적 $\left(1225 \mathrm{~cm}^{2}\right)$ 과 각 정점에서 채집된 거머리말 개체수를 고려할 때 1 회의 방형구에서 채집된 거머리말의 평균 개 체수는 15.25 개체이다.

한편, 음향 조사에서 개개 ping의 탐지 면적은 $6^{\circ}$ 의 좁 은 음향 빔 폭을 고려할 때 거머리말이 가장 많이 분포하 는 수심 $2 \mathrm{~m}$ 에서 약 $345.15 \mathrm{~cm}^{2}$ 의 탐지 면적을 가지게 된 다. 이러한 음향 탐지 면적은 1 회 방형구 면적의 $28 \%$ 에 해당한다. 음향 방법에서 거머리말의 존재 유무만 판정하 므로 음향 탐지 면적 내의 거머리말의 개체수 추정은 방 형구에서 관측된 거머리말의 평균 개체수와 두 방법에서 의 면적의 비율로 계산하였다. 즉, 방형구에서 채집된 거 머리말의 평균 개체수는 15.25 개체이고, 음향 탐지 면적은 1 회 방형구 면적의 $28 \%$ 에 해당하므로 거머리말이 존재하 는 개개 ping에서 평균 개체수는 약 4.3 개체에 해당한다. 음향 자료를 통한 거머리말의 존재 지표 $(N, p i n g)$ 는 1 cycle을 이루는 15 개 ping에 대한 값이므로 이때 15 ping의 탐지 면적은 $5177.19 \mathrm{~cm}^{2}$ 이고, 이 값을 단위 면적 $\left(\mathrm{m}^{2}\right)$ 으로 변환하면 약 0.52 배에 해당한다. 따라서 방형구 로부터 채집된 자료와 음향 조사를 통한 $1 \mathrm{cycle}$ 의 음향 자료로부터 거머리말의 건조 중량 $\left(\rho, \mathrm{g} \mathrm{DW} / \mathrm{m}^{2}\right)$ 계산은 다음과 같이 표현된다.

$$
\rho=\frac{[0.86 \mathrm{~g} / \text { indi. }] \times[N] \times[4.3 \text { indi. } / \text { ping }]}{0.52 \mathrm{~m}^{2}}, \mathrm{~N}>0
$$

23개 음향 정선에 대해 각각의 정선에서 계산된 평균 
Table 3. Mean biomass along each acoustic transect and total biomass of the seagrass, Zostera marina $\mathrm{L}$.

\begin{tabular}{|c|c|c|c|c|}
\hline $\begin{array}{c}\text { Transect } \\
\#\end{array}$ & $\begin{array}{c}\text { Distance } \\
\text { (m) }\end{array}$ & $\begin{array}{l}\text { \# of } \\
\text { cycle }\end{array}$ & $\begin{array}{c}\text { Mean } \\
\text { biomass } \\
\left(\mathrm{g} \mathrm{DW} / \mathrm{m}^{2}\right)\end{array}$ & Statistical analysis \\
\hline 1 & 606 & 140 & 88.59 & \multirow{23}{*}{$\begin{array}{l}\text { Weighted mean } \\
\left(\mathrm{g} \mathrm{DW} / \mathrm{m}^{2}\right)=56.55 \\
\text { Survey area }\left(\mathrm{m}^{2}\right)= \\
1,840,000\end{array}$} \\
\hline 2 & 627 & 138 & 81.17 & \\
\hline 3 & 660 & 195 & 67.68 & \\
\hline 4 & 701 & 141 & 87.46 & \\
\hline 5 & 797 & 204 & 68.34 & \\
\hline 6 & 810 & 215 & 58.29 & \\
\hline 7 & 703 & 185 & 61.96 & \\
\hline 8 & 697 & 158 & 76.15 & \\
\hline 9 & 592 & 142 & 52.34 & \\
\hline 10 & 567 & 141 & 59.35 & \\
\hline 11 & 484 & 117 & 51.74 & \\
\hline 12 & 424 & 112 & 51.41 & \\
\hline 13 & 392 & 137 & 25.37 & \\
\hline 14 & 433 & 134 & 40.73 & \\
\hline 15 & 350 & 119 & 39.31 & \\
\hline 16 & 364 & 116 & 78.25 & \\
\hline 17 & 482 & 80 & 37.46 & \\
\hline 18 & 423 & 92 & 74.87 & \\
\hline 19 & 430 & 89 & 30.78 & \\
\hline 20 & 466 & 97 & 70.64 & \\
\hline 21 & 461 & 99 & 22.11 & \\
\hline 22 & 466 & 85 & 52.51 & \\
\hline 23 & 2566 & 1214 & 48.73 & \\
\hline
\end{tabular}

건조 중량은 만 안쪽의 21 번 정선에서 $22.11 \mathrm{~g} \mathrm{DW} / \mathrm{m}^{2}$ 로 최소 값을, 만 입구의 1 번 정선에서 $88.59 \mathrm{~g} \mathrm{DW} / \mathrm{m}^{2}$ 로 최 대 값을 나타냈으며, 각각의 음향 정선에서 계산된 평균 값을 가중 평균하여 계산한 음향 조사 지역의 전체 평균 생체량(biomass)는 $56.55 \mathrm{~g} \mathrm{DW} / \mathrm{m}^{2}$ 으로 계산되었다(Table 3). 이전 연구 자료에서 인근의 광양만에서 실시된 추계 채집 자료에서 거머리말의 생체량은 $38.8-83.2 \mathrm{~g} \mathrm{DW} / \mathrm{m}^{2}$ 의 분포를 보인다고 조사되었다(허 등 1998). 추계 시기의 이러한 생체량 분포는 음향 자료로부터 계산된 22.11 $88.59 \mathrm{~g} \mathrm{DW} / \mathrm{m}^{2}$ 와 비교했을 때 큰 차이를 보이고 있지 않 아 좁은 지역일지라도 분포 편차가 심한 거머리말 서식처 에서 음항을 이용한 현존량 추정이 가능함을 보여주고 있 다. 조사 지역의 전체 면적 $\left(1,840 \times 10^{3} \mathrm{~m}^{2}\right)$ 을 고려할 때, 음향 조사가 실시된 지역에서 거머리말의 전체 건조 중량 은 약 104.05톤 정도로 추정되었으며, 이때 변량 계수는 $25.77 \%$ 였다.

음향 자료로부터 거머리말의 자원량을 추정하는 과정에 서 현장에서 채집되는 거머리말의 개체수와 개체의 평균 중량은 중요한 요소이다. 따라서, 거머리말의 채집을 조사
지역 전체에 걸쳐 골고루 실시해야 되며, 방형구 내의 평 균 개체수 및 무게 자료를 도출해야만 전체 자원량 추정 의 정확도를 증가시킬 수 있을 것이다. 본 연구에서는 연 구의 주요 목적을 해초류의 수직 및 공간 분포 특성 파악 에 두었으므로 상대적으로 거머리말의 채집을 조사 지역 에서 골고루 실시하지 못하여 음향 자료로부터 추정된 거 머리말의 전체 중량에 오차가 존재할 수 있다. 그러나 이 러한 문제는 거머리말의 채집 자료가 좀 더 보강된다면 오차를 줄일 수 있으며, 따라서 연안역에서 해초류의 전체 자원량을 추정하는데 음향을 이용하는 방법이 유용한 수 단으로 사용될 수 있을 것이다.

한편, 수중에 발사된 음파에 대해 강한 음향 산란체로 작용하는 것은 해초류 이외에 해저면과 어류를 고려할 수 있다. 해저면의 경우 고정된 면으로 수신 강도가 저질 상 태에 따라 일정한 특성이 있어 음향 자료 처리 과정에서 제외가 가능한 부분이다. 또 다른 산란체인 어류의 경우 해초류와 분리되어 존재하는 경우에는 음향 자료 처리 과 정에서 어려움이 없다. 그러나 해초류와 어류가 음향 탐지 면적에 동시에 존재하는 경우는 수신 음향 강도에 해초 에 의한 신호와 동시에 수신되어 해초류의 양 추정이 과 추정될 가능성이 있다. 어류의 종 조성이나 크기에 따라 변화가 있지만 일반적으로 개개 어류의 음향 반사 강도 는 -50 -30 dB의 범위 내에 분포한다(MacLennan and Simmonds 1992). 그러나 본 연구에서 해초 체내에 포함 되어 있는 기포에 의해 음향 반사 강도는 $-20 \mathrm{~dB}$ 이상까 지 증가하는 것으로 나타나고 있다. 따라서 조사 시기에 해초 서식처에 어류가 존재할 가능성이 크지만 어류에 의 한 해초의 음향 신호에 영향을 주기 위해서는 대규모 어 군이 존제해야만 할 것이다. 따라서 해초의 수직 분포 및 공간 분포를 알기 위한 음향 조사에서 소규모 어군의 영 향은 크지 않을 것으로 판단되나, 밀도 추정의 경우에는 정확도에 일부 영향을 주게 된다. 이러한 문제점의 대안으 로 해초류 서식처에 어류 분포의 가능성이 가장 적은 동 계 기간에 조사를 실시하는 것을 고려할 수 있다. 즉, 해초 의 계절적인 분포 특성이 다르게 나타날 수 있지만 동계 시기에는 해초 서식처에 분포하는 어류상이 급격히 감소 하는 시기이므로 이 시기에 음향 조사를 실시하면 음향 자 료에서 어류에 의한 효과를 최소화시킬 수 있을 것이다.

연안의 해초류는 산업화에 따른 서식처의 파괴로 점차 분포 면적이 줄어 들어 생태계 및 수산 자원 화복을 위해 복원과 관련된 연구가 활발히 진행되고 있다. 해초류 서식 처 복원에 앞서 선행되어야 할 문제는 우선 해초 서식처 에 대한 현황 파악이 중요한 문제이다. 기존에 사용되는 방형구를 이용하는 방법과 더불어 해초의 공간 범위, 조사 시간, 전 수층의 탐지 능력 등 많은 장점을 가지고 있는 수중음향 기법을 사용한다면 연안 해초 서식처 연구에 또 
다른 방법론을 제공할 것이다. 또한 이러한 방법은 대청 호, 소양호 등 우리나라의 대형 호수나 4대강 유역에서 담 수 식물의 공간 분포도 작성에 직접적으로 적용이 가능하 여 담수 연구에도 활용이 가능할 것이다.

\section{5. 결 론}

본 연구에서는 우리나라 연안에 광범위하게 분포하고 있는 해초의 수직 및 공간 분포 연구를 위해 기존의 방형 구를 이용한 방법 이외에 새로운 접근 방법의 하나로 수 중음향 기법을 적용하였다. 대상 연구 지역은 남해도 북쪽 의 동대만이었으며 조사 시기는 2005년 9월 하순이었다. 음향 조사에 사용된 주파수는 $420 \mathrm{kHz}$ 분할빔으로 음향 센서를 소헝 예인체에 설치하여 조사선의 측면에 고정시 킨 후 약 3 4 노트의 속도로 연속 관측을 실시하였다. 조 사 지역이 좁은 만 지역임을 고려하여 위치 정보는 DGPS 를 사용하여 음향 자료와 동시에 저장하였으며 음향 정선 은 총 23개 정선으로 구성되었다. 음향 자료가 간접적인 자료이므로 직접적인 자료와 비교하기 위하여 수중카메라 와 다이빙을 통한 직접 채집을 8회 실시하였다. 조사 결 과, 해초는 수심 $3.5 \mathrm{~m}$ 를 중심으로 상부 수심에만 존재하 였으며, 공간적인 분포로는 동대만 입구 부분, 가운데 평 지 부분 및 만 안쪽의 서쪽 부분에 주로 대규모로 분포하 는 것으로 나타나고 있었다. 이러한 연구 결과는 해초의 분포가 좁은 규모의 만이지만 공간적으로 분포 변화가 크 게 나타남을 보여주고 있다. 직접적인 자료인 수중카메라 영상과 채집 자료를 음향 자료와 비교하였을 때 해초 분 포 특성의 상관성이 양호함을 보여주고 있었다. 한편, 채 집 자료로부터 우점종이 거머리말로 나타났으며 이들 자 료와 음향 자료로부터 거머리말의 전체 생체랑을 추정하 고자 하였다. 23개 음향 정선에 대한 거머리말의 생체량 은 $22.11 \sim 88.59 \mathrm{~g} \mathrm{DW} / \mathrm{m}^{2}$ 였으며 전체 정선의 평균 생체 량은 $56.55 \mathrm{~g} \mathrm{DW} / \mathrm{m}^{2}$ 로 계산되었다. 조사 지역의 전체 면 적 $\left(1,840 \times 10^{3} \mathrm{~m}^{2}\right)$ 을 고려할 때, 음향 조사가 실시된 지역 에서 거머리말의 전체 건조 중량은 약 104.05 톤 정도로 추정되었으며, 이때 변량 계수는 $25.77 \%$ 였다. 본 연구로 부터 연안에 서식하는 해초의 공간 및 수직 분포 연구에 기존의 직접적인 방법 이외에 수중음향을 이용한 간접적 인 방법이 유용한 수단임을 알 수 있었으며, 이러한 연구 방법은 해양 생태계 연구 이외에 호수 생태계 연구에도 직접적으로 적용 가능할 것이다.

\section{사 사}

본 연구는 한국해양연구원이 수행하고 있는 해양수 산부의 "통영해역의 바다목장화 개발연구용역 사업
(BSPM33900-1717-3)"과 한양대학교가 수행하고 있는 한 국과학재단의 "목적기초연구(R01-2003-000-11658-0)"의 지원을 받아 수행되었음. 현장에서 홀로 거머리말의 다이 빙 채집 및 자료 처리를 해준 이인우 군에게 감사를 표합 니다.

\section{참고문헌}

라형술, 윤관섭, 나정열. 2005. 거머리말 서식지의 고주파 후 방산란 특성. 한국음항학회지, 24, 97-102.

이상룡. 2001. 한국산 거머리말속(Zostera, Zosteraceae)의 생 태 및 분류학적 특성에 관한 연구. 이학박사 학위논문, 한 양대학교. $167 \mathrm{p}$.

이상룡, 이성미, 최청일. 2005. 남해 연안에 생육하는 거머리 말 개체군의 생물 계절학과 생식 능력. Ocean \& Polar Res., 27, 67-74.

이성미, 이상룡, 최청일. 2005. 한국산 해초 포기거머리말, 수 거머리말, 애기거머리말과 거머리말의 생물계절학. Ocean \& Polar Res., 27, 125-133.

이태원, 문형태, 황학빈, 허성회, 김대지. 2000. 남해 안골만 해초밭 어류 종조성의 계절 변동. 한국수산학회지, 33 , 439-447.

허성회, 곽석남. 1997. 광양만 해초밭에 서식하는 실고기 (Syngnathus schlegeli)의 식성. 한국수산학회지, 30, 896902.

허성회, 곽석남, 남기완. 1998. 광양만 해초밭에서 해초와 착 생해조류의 계절 변동. 한국수산학회지, 31, 56-62.

Aioi, K. 1980. Seasonal changes in the standing crop of eelgrass (Zostera marina L.) in Odawa Bay, Central Japan. Aquat. Bot., 8, 343-354.

Bergstedt, R.A. and D.R. Anderson. 1990. Evaluation of line transect sampling based on remotely sensed data from underwater video. Tran. Am. Fish. Soc., 119, 86-91.

BioSonics. 2005. X-Series Echosounder and Visual Acquisition 5.0 User Guide. BioSonics Inc. Seattle, USA.

Connolly, R.M. 1994. Comparison of fish catches from a buoyant population net and a beach net in shallow water seagrass habitat. Mar. Ecol. Prog. Ser., 109, 305-309.

Dennison, W.C. and R.S. Alberte. 1985. Role of daily light period in the depth distribution of Zostera marina (eelgrass). Mar. Ecol. Prog. Ser., 25, 51-61.

Dobson, J.E., E.A. Bright, R.L. Ferguson, D.W. Field, and L.L. Wood. 1995. NOAA Coastal Change Analysis Program (C-CAP): Guidance for Regional Implementation. NOAA Technical Report NMFS 123. 92 p.

Freitas, R., S. Silva, V. Quintino, A.M. Rodrigues, K. Rhynas, and W.T. Collins. 2003. Acoustic seabed classification of marine habitats: Studies in the western coastal-shelf area of Portugal. ICES J. Mar. Sci., 60, 599-608. 
Guest, M.A., R.M. Connolly, and N.R. Loneragan. 2003. Seine nets and beam trawls compared by day and night for sampling fish and crustaceans in shallow scagrass habitat. Fish. Res., 64, 185-196.

Hoffman, J.C., J. Burczinski, B.M. Sabol, and M. Heilman. 2002. Digital Acoustic System for Ecosystem Monitoring and Mapping Assessment of Fish, Submersed Aquatic Vegetation, and Bottom Substrata Classification. 6th ICES Symposium on Acoustic in Fisheries and Aquatic Ecology, France.

Komatsu, T., C. Igarashi, K. Tatsukawa, S. Sultana, Y. Matsuoka, and S. Harada. 2003. Use of multi-beam sonar to map seagrass beds in Otsuchi Bay on the Sanriku Coast of Japan. Aquat. Living Resour., 16, 223230.

Lee, S.Y., C.J. Kwon, K.S. Lee, and C.I. Choi. 2002. Distribution of eelgrass, Zostera marina $\mathrm{L}$. on coasts of the Korean Peninsula: Preliminary study for eelgrass restoration. Ocean \& Polar Res., 24, 55-61.

MacLennan, D.N. and E.J. Simmonds. 1992. Fisheries Acoustics. Chapman \& Hall, London. 325 p.

Mumford, T.F. Jr., S. Wyllie-Echeverria, and J. Norris. 1995. Inventory of eelgrass (Zostera spp.) in Washington State. p. 508-515. In: Puget Sound Research '95 Proceedings. Puget Sound Water Quality Authority, Olympia, WA.
Norris, J.G, S. Wyllie-Echeverria, T. Mumford, A. Bailey, and T. Turner. 1997. Estimating basal area coverage of subtidal seagrass beds using underwater videography. Aquat. Bot., 58, 269-287.

Sabol, B.M., E. McCarthy, and K. Rocha. 1997. Hydroacoustic basis for detection and characterization of eelgrass (Zostera marina). p. 679-693. In: Proceedings of the 4th Conference on Remote Sensing of Marine Environments.

Sabol, B.M. and J. Burczinski. 1998. Digital echo sounders system for characterizing vegetation in shallow-water environments. p. 165-171. In: Proceedings of the 4th European Conference on Underwater Acoustics, Rome, Italy.

Sabol, B. M. and S.A. Johnston. 2001. Innovative Techniques for Improved Hydroacoustic Bottom Tracking in Dense Aquatic Vegetation. ERDC/EL MP-01-2, U.S. Anmy Engineer Research and Development Center, Vicksburg, MS.

Short, F.T., R.G. Coles, and C. Pergent-Martini. 2001. Global seagrass distribution. p. 5-10. In: Global Seagrass Research Methods. ed. by F.T. Short and R.G. Coles. Elsevier, Amsterdam. 